\title{
Understanding Internal Driven Factors of Household Intention to Upgrade Waste Treatment System: A Case Study of Small- scale Cow Farming in Le Chi Commune, Gia Lam, Ha Noi
}

\author{
Nguyen Thi Huong Giang* \\ Faculty of Environment, Vietnam National University of Agriculture, Trau Quy, Gia Lam, Hanoi, Vietnam
}

Received 14 November 2017

Revised 31 December 2017; Accepted 21 March 2018

\begin{abstract}
Livestock waste management at household level is one of the biggest challenges for environmental managers in Vietnam for several years. Understanding internal factors, which influent waste management behavior of household, is extremely important to obtain successful environmental protection strategy. The study was conducted in a peri-commune of Ha Noi, Le Chi Commune in order provide useful information for better understanding about farmers intention in innovating their current waste treatment system. Through applying behavioral approach, study had interviewed 85 households to obtain necessary information for correlation models. The study found no evidence which present the relationship between the intention to upgrade the system and farmers' current farming situation as well as farmers' satisfaction on environmental performance of the present applied treatment systems. However, the intension highly positive correlated to the purpose to increase farming scale $(r=.490, \mathrm{p}<.001)$, the cow barn expansion $(r=.675, \mathrm{p}<.001)$ and fairly correlated to the satisfaction of household about the time saving criteria of current waste processed methods $(\mathrm{r}=-.304, \mathrm{p}<0.001)$. These results of this study could provide considerable information for waste management strategies in this commune.
\end{abstract}

Keywords: Waste management, household intention, pro-environmental behavior, environmental protection attitudes.

\section{Introduction}

Small-scale cattle production is the most common farming system in Vietnam [1, 2]. Hitherto, it has contributed many positive impacts on poverty reduction and rural

\footnotetext{
* Tel.: 84-915243136.

Email: giangnguyenln@gmail.com

https://doi.org/10.25073/2588-1094/vnuees.4215
}

development. Nevertheless, livestock waste treatment situation of this sector has challenged environmental management actors for several years. According to the annual report of MONRE for the period 2011-2015, waste from livestock sector, especially at household scale was one of the biggest source of pollution for the rural environment [3]. The statistic record of Department of Livestock Department [1] showed that, only $40 \%$ of solid waste from 
livestock sector was processed before discharge to environment and the small-scale farming, especially at highly populated areas, makes situation even worse.

Reviewing the literature in this field recently, it is able to see the significant number of papers aiming to investigate the environmental impacts and technical innovations or environmental policy to resolve the problems [4]. However, as Institute of Environment and Sustainable Development claimed in their report of the Biogas Assessment Project (2011), the decision making process farmers and their own experience on waste treatment application were not well investigated in recent scientific studies. Without doubt, associating with the policy and technology factors, the success of waste management depends highly on household motivation, other internal factors of households. The lack of this information could result in limited effective policies or even failure of the policy implementation.

This study carried out in a peri-urban area of $\mathrm{Ha}$ Noi, Le Chi Commune. Through gathering information of household farming situation and waste treatment system, their own perception on the systems' effectiveness as well as production plan, the study uses correlation the waste treatment system in their own conditions and the binary regression analysis to explore the understand the complexity of farmers' decision making process and provided useful information for more appropriate livestock waste management policy at rural area.

\section{Methodologies and study area}

\subsection{Study area}

Le Chi is a small commune of Gia Lam District, located in the sub-region of Duong River. In 2016, the total population of this commune was over 10000 people, population density was exceed 1200 people per $\mathrm{km} 2$ and nearly $60 \%$ of total labour working in agriculture sectors. Beef cattle production was considered as the most important part of agricultural economy of Le Chi. The local purchased rate was from 40 million VND to 50 million VND per cow so it became the main income source of many families. However, as a consequence of poor waste management practice, the commune had been experiencing many serious environmental problems [5].

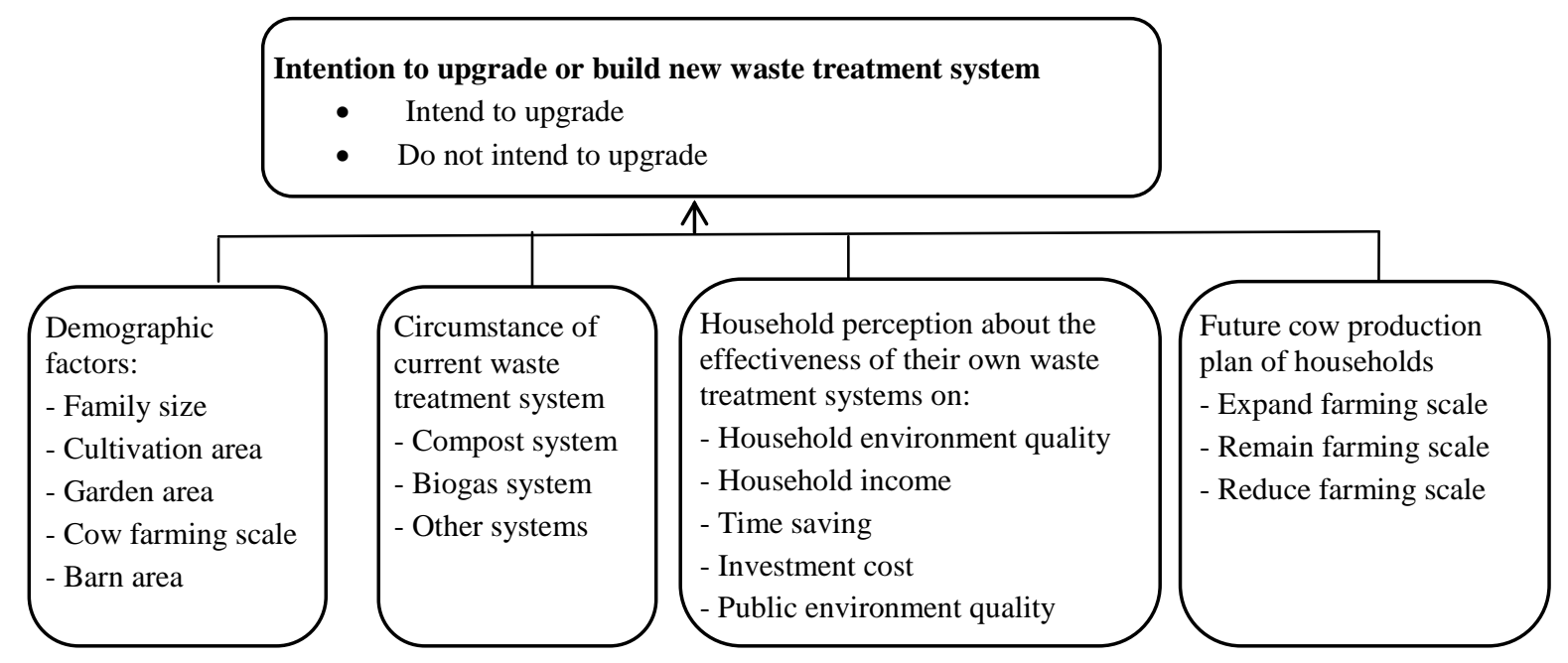

Figure 1. Analytical framework of intention to upgrade or build new waste treatment system at household scale 


\subsection{Data analysis}

The data applied in this study was collected from two sources: household structured questionnaire and secondary data from local reports and other studies. In the questionnaire survey, we selected 85 households taking over $10 \%$ proportions of total 820 cow farms in Le Chi Commune to gather necessary information. The main contents of questionnaire are summarized in Figure 1, which include necessary information for analytical framework. The study hypothesized that, excluding external effects, households intention might be influenced by four main groups of factors: household demographic and farming scale, their current waste treatment system, their own perception on the effectiveness of current waste treatment system, and finally the future production and waste treatment plan.

\subsection{Data collection methods}

All the computations in this paper were processed by IPM SPSS Statistics 20.0. We firstly used descriptive statistic to provide general picture of cow farming and waste treatment in Le Chi Commune. In the following steps, Spearman correlation analysis was applied to find out the relationships between household intention and proposed potential factors. Finally, the variances, which were significant correlated with household intention, were used in multiple linear regression model to predict their effects on household intention. In this model, households' intention was explanatory variable and the others were dependent variables. The measure scales of all variables are summarized in Table 1.

Table 1. Measure scales of correlation hypothesis of variables

\begin{tabular}{|c|c|c|c|}
\hline Variables & Codes & Types of measures & $\mathrm{H}$ \\
\hline Household intention & INTENT & Dummy (1 if yes, 0 if no) & \\
\hline Family size & SIZEFA & Numbers & 1 \\
\hline Cow production experience & COWEPR & Numbers & 2 \\
\hline Garden areas & GARDEN & $\mathrm{m} 2$ & 3 \\
\hline Barn areas & BARN & $\mathrm{m} 2$ & 4 \\
\hline Cultivation areas & $\begin{array}{c}\text { CULTIVATIO } \\
\mathrm{N}\end{array}$ & $\mathrm{m} 2$ & 5 \\
\hline Number of cows in 2017 & COWS & number & 6 \\
\hline Biogas application & BIOGAS & Dummy ( 1 if yes, 0 if no) & 7 \\
\hline Compost application & COMPOST & Dummy ( 1 if yes, 0 if no) & 8 \\
\hline $\begin{array}{c}\text { Others waste treatment system(discharge } \\
\text { cow waste into environment or fresh } \\
\text { manure application) }\end{array}$ & OTHERS & Dummy ( 1 if yes, 0 if no) & 9 \\
\hline Household environment quality & HHENVI & $\begin{array}{c}\text { Likert five point scales (5: very effective, } 4 \text { : } \\
\text { effective; } 3 \text { : moderate effective; } 2 \text { : ineffective; } \\
\text { 1: very ineffective) }\end{array}$ & 10 \\
\hline Household income & INCOME & $\begin{array}{c}\text { Likert five point scales (5: very effective, } 4 \text { : } \\
\text { effective; } 3 \text { : moderate effective; } 2 \text { : ineffective; } \\
\text { 1: very ineffective) }\end{array}$ & 11 \\
\hline Time saving & TIME & $\begin{array}{c}\text { Likert five point scales (5: very effective, } 4 \text { : } \\
\text { effective; } 3 \text { : moderate effective; } 2 \text { : ineffective; } \\
\text { 1: very ineffective) }\end{array}$ & 12 \\
\hline
\end{tabular}




\begin{tabular}{cccc}
\hline Investment cost & ICOST & $\begin{array}{c}\text { Likert five point scales (5: very effective, } 4: \\
\text { effective; 3: moderate effective; } 2: \text { ineffective; } \\
\text { 1: very ineffective) }\end{array}$ & 13 \\
Local environment & PLENVI & $\begin{array}{c}\text { Likert five point scales (5: very effective, } 4: \\
\text { effective; 3: moderate effective; } 2: \text { ineffective; } \\
\text { 1: very ineffective) }\end{array}$ & 14 \\
Increase farming scale & IFSCALE & Dummy (1 if yes, 0 if no) & 15 \\
Remain current farming scale & RFSCALE & Dummy (1 if yes, 0 if no) & 16 \\
Reduce farming scale & RDSCALE & Dummy (1 if yes, 0 if no) & 17 \\
Expand the area of the cow barn & EBARN & Dummy (1 if yes, 0 if no) & 18 \\
\hline
\end{tabular}

Note: $H=$ Hypothesized relationship with households' intention.

In correlation analysis, we used p-value to test the significant of correlation coefficient. If the pvalue is less than the significant level $(\alpha=0.05)$, we reject the null hypothesis ( $\mathrm{H} 0)$ and conclude the $\mathrm{H}$ hypothesis (being numbered from 1 to 18 ) that variable has relationship with household intention. If the $p$-value is bigger than the significant level $(\alpha=0.05)$, we confirm the null hypothesis which means proposed variable has no relationship with household intention.

\section{Results and discussion}

\subsection{Study area and general picture beef cattle farming}

General information of cow farming and waste treatment situation in Le Chi

Some main descriptions of interviewed households are summarized in Table 2, Figure 2 and Figure 3.

Data in the Table 2 presents the moderately differences among cow farms in Le Chi Commune. Each household had small garden, averagely only $54.6 \mathrm{~m} 2$ household-1, nonetheless, some families had no garden, and some had a large one with the total area up to over $2000 \mathrm{~m} 2$. In term of cow barn, the regular space for the cow barn of Le Chi was $31.5 \mathrm{~m} 2$, however, the smallest barn was 42 times smaller than the biggest barn $(4 \mathrm{~m} 2$ and 168 $\mathrm{m} 2$ ). Most of cow barns were built next to the main house or the kitchen with average distance was $9.4 \mathrm{~m}$. Interviewed households produced different type of crops, which were vegetable, corn, elephant grass and rice with the area around $2000 \mathrm{~m} 2$, nonetheless, some families had very limited cultivation land, only $10 \mathrm{~m} 2$.

The small and extremely small production scale was the most common characteristics of cow farm in Le Chi. $90 \%$ of households had from one to five cows and the rest of households raised from six to ten cows and only one household currently had up to nineteen cows at the time we conducted this study Figure 2. This was a typical cattle farming scale in Gia Lam district and also in many places of Vietnam [1-3]. In addition, cows mostly were raised by captivity method $(50 \%$ of households), only $5 \%$ of households grazed their cows and the rest of households combined both methods (grazing and captivity).

Table 2. Characteristics of households and farming scale

\begin{tabular}{ccccc}
\hline Characteristics & Unit & $\begin{array}{c}\text { Mini } \\
\text { mum }\end{array}$ & $\begin{array}{c}\text { Maxi } \\
\text { mum }\end{array}$ & $\begin{array}{c}\text { Mean } \\
\pm \text { SD }\end{array}$ \\
\hline Family size & $\begin{array}{c}\text { pers } \\
\text { on }\end{array}$ & 2 & 10 & $\begin{array}{c}4.3 \pm \\
1.6\end{array}$ \\
\hline Number of cow & head & 1 & 19 & $\begin{array}{c}3.2 \pm \\
2.8\end{array}$ \\
\hline Areas of garden & $\mathrm{m} 2$ & 0 & 2160 & $\begin{array}{c}54.6 \pm \\
27.2\end{array}$ \\
\hline $\begin{array}{c}\text { Areas of } \\
\text { cultivation land }\end{array}$ & $\mathrm{m} 2$ & 10 & 7200 & $\begin{array}{c}2320.4 \\
\pm 131.8\end{array}$ \\
\hline $\begin{array}{c}\text { Areas of cow } \\
\text { barn }\end{array}$ & $\mathrm{m} 2$ & 4 & 168 & $\begin{array}{c}31.5 \\
\pm 3.1\end{array}$ \\
\hline $\begin{array}{c}\text { Distance from } \\
\text { cow barn to the }\end{array}$ & $\mathrm{m}$ & 1 & 30 & $\begin{array}{c}9.4 \pm \\
\text { main house }\end{array}$ \\
& & & & 0.7 \\
\hline
\end{tabular}




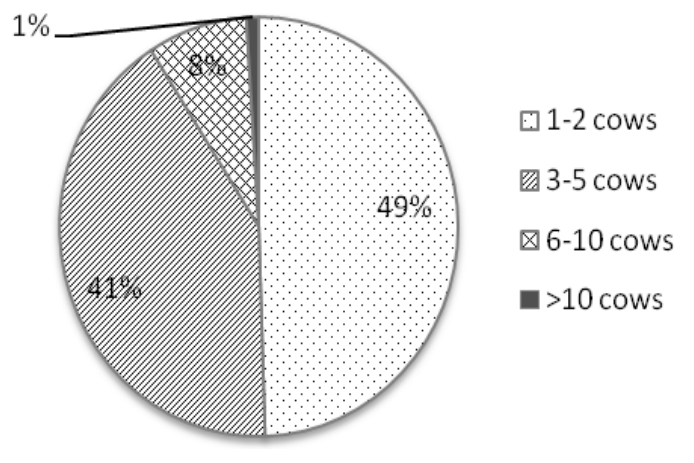

Figure 2. Farming scale of cow production in Le Chi

Cow farming inside residential areas with very limited space definitely trigger many negative impacts on environment as well as living conditions of villagers if farmer do not implement appropriate solution [5].

Study also investigated the cow waste treatment systems which are currently applied in this area. Figure 3 pointed out two most common waste treatment systems in Le Chi, which were biogas and traditional compost systems, applied by $38 \%$ and $53 \%$ of households respectively. The rest of families fertilized fresh manure for crops and the others directly discharge cow waste into environment. None of farmer sold manure or used it for red worm composting Figure 3.

Composting system was the most implemented solution for cow waste treatment in the commune. Generally, farmers mixed fresh manure with other residues like rice straw, husk and kitchen ask. The mixture was composted in an open-pit or a heap (only one household covered the pit by plastic sheet). The old method without effective microorganisms (EM) adding still was used so the composed process normally takes from six to seven months. From $80 \%$ to $100 \%$ of manure was collected to compost, however, many farmers admitted, a part of total waste volume sometimes was released into surrounding areas,

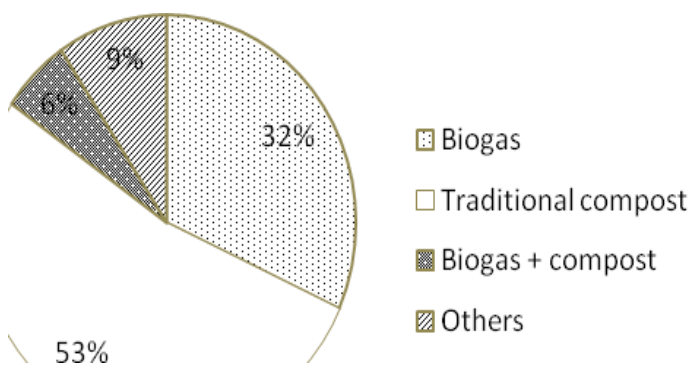

Figure 3. Current cow waste treatment system in Le Chi $(\%)$

especially $100 \%$ of the cow urine was discharged into local sewage system.

There were $38 \%$ of interviewed households applying biogas and over one-third of biogas users only raised from one to two cows. The average usage time of biogas plant was nearly eight years, some had been used for 20 years with the investment cost ranged from 1.2 million VND to 30 million VND per plant and mostly came from households' own budget. Waste in biogas system in Le Chi mainly was not separated ( $81 \%$ of interviewed households). The digester was constructed by concrete and composite and the biggest digester was far exceed the smallest one ( $30 \mathrm{~m} 3$ and $1.2 \mathrm{~m} 3)$.

Households' evaluation on the effectiveness of their current waste treatment system

The perspective of farmers on current system's effectiveness might impacts on farmers' decision to upgrade or maintain waste treatment system in the future. Study used likert five-point scale to classify effectiveness levels regarding to five criteria: environmental quality of household, household income, time saving, investment cost and local environment. Table 3 shows the independent sample t-test analysis results to compare the mean results of evaluation between two groups: group of biogas users and group of compost users. 
Table 3. The effectiveness of waste treatment system based on farmers' perception

\begin{tabular}{ccccccc}
\hline \multirow{2}{*}{ No. } & Variables & \multicolumn{2}{c}{$\begin{array}{l}\text { Biogas and biogas } \\
+ \text { compost }(\mathrm{n}=32)\end{array}$} & \multicolumn{2}{c}{ Compost $(\mathrm{n}=45)$} & \multirow{2}{*}{$\begin{array}{c}\text { Sig. } \\
\text { (2-tail) }\end{array}$} \\
\cline { 3 - 6 } & & Mean & SD & Mean & SD & \\
\hline 1 & $\begin{array}{c}\text { Household } \\
\text { environment quality }\end{array}$ & 4.4 & 0.7 & 3.6 & 1.0 & 0.00 \\
2 & Household income & 4.2 & 0.7 & 3.9 & 0.7 & 0.08 \\
3 & Time saving & 4.2 & 8.9 & 3.6 & 0.9 & 0.06 \\
4 & Investment cost & 3.5 & 0.7 & 4.0 & 0.9 & 0.04 \\
5 & Local environment & 4.3 & 0.6 & 3.6 & 0.7 & 0.00 \\
\hline
\end{tabular}

Note: $n=$ number of interviewed households

Referring to the t-test analysis three out of five variables have $p<0.05$ and the other two variables have $p=0.08$ and 0.06 , which states the mean values of all variables are significant and have certain trend toward significance. In overall, the results show the averagely satisfaction of most farmers about their current waste treatment system. However, biogas utilizers tended to perceive more effectiveness than compost systems users, except the investment cost.

Most of biogas user stated the improvement of environment quality both inside and outside their house by observing the reduction of bad odor and flyers. Biogas system also reduced households' expenditure via producing gas for cooking, heating or lighting. In addition, farmers quantified this was time saving method, except few farmers who separate liquid and solid waste in the integrated systems, which combined compost and biogas. The most concern of biogas utilizers were investment cost and some farmers also mention the difficulties to settle a digester due to the limited space.

Compost systems were applied by larger proportion of farmer in comparison to biogas plants (53\% of interviewed households). The highest effective points of this system were the low investment cost and then the income generation aspect through providing fertilizer for crops: rice, corn, elephant grass and sweet potatoes Table 4. However, many people claimed this method consume time and effort because it required to collect manure daily and some households even had to transport the manure for a distance by bicycle or bike to the pit or heap which was dug in the field (in their own plot). In term of environment quality, the results show the less satisfied rate of the compost users than the biogas users. Regarding to the local environmental impacts, some people claimed this method might affect water quality and release bad smell in public space.

Table 4. The use of waste after treatment process

\begin{tabular}{|c|c|c|c|c|c|c|}
\hline & Fertilizer & $\begin{array}{c}\text { Electricity } \\
\text { and heating } \\
\text { power }\end{array}$ & $\begin{array}{c}\text { Cooking } \\
\text { gas }\end{array}$ & $\begin{array}{c}\text { Watering } \\
\text { plants }\end{array}$ & $\begin{array}{l}\text { Discharge } \\
\text { to fish } \\
\text { ponds }\end{array}$ & $\begin{array}{l}\text { Discharge to } \\
\text { environment }\end{array}$ \\
\hline Effluent after biogas $(n=32)$ & 0 & 0 & 0 & $6 \%$ & $9 \%$ & $85 \%$ \\
\hline $\begin{array}{l}\text { Residual sludge after biogas } \\
\qquad(\mathrm{n}=32\end{array}$ & $31 \%$ & 0 & 0 & 0 & $3 \%$ & $6 \%$ \\
\hline Gas from biogas $(n=32)$ & 0 & $63 \%$ & $37 \%$ & 0 & 0 & 0 \\
\hline Compost $(n=49)$ & $100 \%$ & 0 & 0 & 0 & 0 & 0 \\
\hline $\begin{array}{l}\text { Effluent from composting } \\
\text { system }(n=49)\end{array}$ & 0 & 0 & 0 & 0 & 0 & $100 \%$ \\
\hline
\end{tabular}


As can be seen from the Table 4, the biggest unsolved problem of cow waste in Le Chi Commune is the untreated liquid waste. In compost system, farmers only collected solid waste and discharged the urine into the local sewage system. The similar situation happened in biogas systems, the untreated effluent after biogas was discharged to environment, sewage or public pond. The villagers in Le Chi had experienced the bad odor and wastewater flowing over the road from the broken or uncovered sewage systems, some public ponds became the polluted point due to the waste accumulation for several years [5].

\subsection{Households' intension to upgrade waste treatment system}

The current situation cow waste management in Le Chi draws out a visible need to improve waste treatment system in this commune. However, by asking farmers "Do you intend to upgrade or built a new construction for waste treatment in the future", we received only 8 out of 85 responses (9\%) say "yes". The rest of households denied for some reasons such as: satisfied with current system, lack of finance, or limited space for expanding the system.

In order to explore the driven factors of households intention, the study also used Spearman correlation analysis to find out its relationship with four groups variances, which are household demographic and farming scale, current applied waste treatment system, households' evaluation on system effectiveness (only for biogas and compost), and finally the production plan (Table 5).

Table 5. Correlations between intension to upgrade waste treatment system of households and potential impact factors

\begin{tabular}{cccc}
\hline Factors & Variances & Spearman & Sig. \\
& Correlation & $(2$-tailed) \\
\hline Household & Family size & -.029 & .789 \\
demographic and & Cow production experience & .037 & .737 \\
farming scale & Garden areas & .101 & .357 \\
(n=85) & Barn areas & .009 & .934 \\
& Cultivation areas & .047 & .530 \\
Current applied & Number of cows in 2017 & .069 & .021 \\
waste treatment & Biogas application &. $.250^{*}$ & .040 \\
system (85) & Compost application & .223 & .757 \\
Satisfaction level of & Others waste treatment system(discharge cow waste into & .034 & .824 \\
households with & environment or fresh manure application) & .026 & .548 \\
current waste & Household environment quality & .070 & .007 \\
treatment system & Household income & $-.304 * *$ & .093 \\
(n=77) & Time saving & .193 & .779 \\
& Investment cost & .033 & .000 \\
Future production & Local environment & $.490^{* *}$ & .001 \\
plan (n=85) & Increase farming scale & $-.356^{* *}$ &. .072 \\
& Remain current farming scale & $.675^{* *}$ & .000 \\
\hline
\end{tabular}

**. Correlation is significant at the 0.01 level (2-tailed)

*. Correlation is significant at the 0.05 level (2-tailed) 
In the Table 5, the positive correlations of household intention were found with the size of cultivation land $(\mathrm{r}=.217, \mathrm{p}=.047)$, the compost application cases $(\mathrm{r}=.223, \mathrm{p}=.040)$, and especially in the case farmer intend to expand farming scale $(\mathrm{r}=.490, \mathrm{p}=.007)$ and cow barn $(\mathrm{r}=.675, \mathrm{p}<.001)$. Household intention had inverse relationship with biogas application case $(\mathrm{r}=-.250, \mathrm{p}=.021)$, the effectiveness on time saving $(r=-.304, p=.007)$ and the case of unchanged farming scale in production plan $(\mathrm{r}=-.356, \mathrm{p}=.001)$. Based on the results we can conclude the acceptance of hypothesis H5, H7, H8, H12, H15, H16 and H18. For other eleven

Table 6 . Results of binary regression analysis

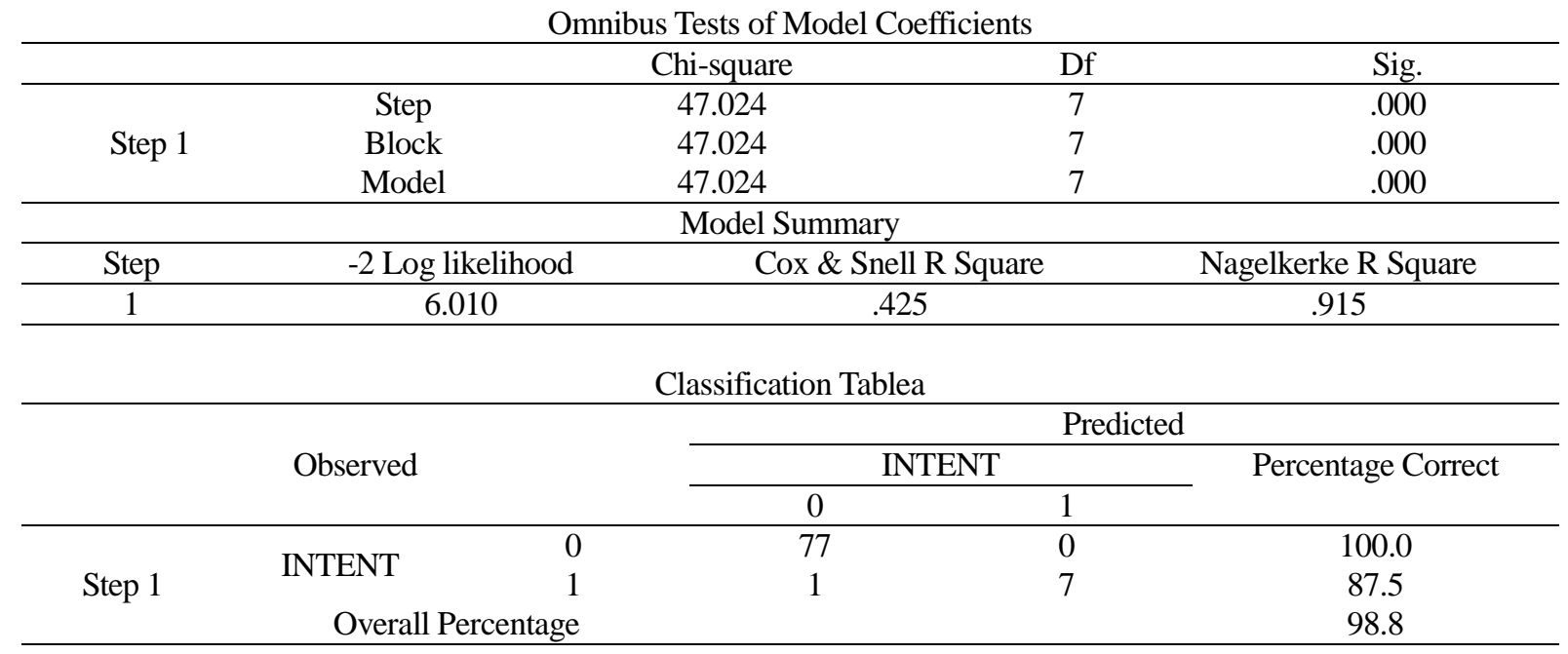

a. The cut value is .500

A test of the full model indicate that the predictors as a set reliably distinguished between intended farmers and non-intended farmers (chi-square $=47.024, \mathrm{p}<0.001$ with $\mathrm{df}$ $=7$ ). Nagellkerke's R2 present strong relationship between prediction and explanatory. Prediction success overall was $98.8 \%$ ( $100 \%$ for decline and $87.5 \%$ for accept).

\subsection{Discussion}

Fairy positive performance of cow waste managemeopnt situation in Le Chi

The initial aim of this study sought to determine the status of waste management in Le Chi Commune. The results showed a fairy variables, the test resulted p-values $>0.05$, thus we accepted the null hypothesis (H0), there was no evidences showing the relationship between these variables with household intention.

In order to evaluate the suitability of these seven factors to explain the households' intension, we applied binary regression model in which households' intention is independent variables and the other seven correlated variables were dependent variables. The regression result is showed in Table 6. 
Huong et al [2], CEM [6] and many other research in different regions of Vietnam $[1,7$, 8]. According to the estimation of MONRE (2014), the total treated waste from livestock sector only take $40 \%-50 \%$ proportion of total waste volume and the data even bigger in at the case of household livestock farming [1]. In addition, study also found the motivated attitudes of farmers in composting system. They were willing to paid time and efforts to transfer manure for long distance from their house to the pit in their field. However, these achievement do not mean the fresh environment of this commune being recovered, the explanation for this problem is going to present in the following parts.

Traditional technological application and low motivations to change current waste management situations

It able to see little advance in term of waste treatment technologies innovation. Nearly $100 \%$ household applied traditional composting method without adding EM or covering so it takes long time to ruin to manure and still release bad odor to the environment. For biogas system, many tanks had small volume or being constructed nearly twenty years. Many farmers had experienced the drawback of household biogas systems which are the insufficient amount of gas for household's demand, the damaged system and the gas leakage. These results match those observed in earlier studies of Vu Thi Thanh Huong et al, Phung Duc Tien et al, Dinh Van Dung et al, and Rajendran [2, 7, $8,9]$. Especially, in all types of waste treatment systems, effluent mostly untreated and became main source of pollution in several villages. The studies also indicated that most of cattle farmers in Le Chi have not approached the others positive waste treatment methods which had been introduced for household waste treatment scale, including EM application, red worm compost or even manure trading.

An anticipated finding was that, none household who did not have waste treatment system intend for new construction in the future to solving waste problems. Only one out of ten farmers had intention to upgrade their current situation though many of them are unsatisfied or somewhat satisfied with environmental performance of the system both inside and outside their houses. This result could present to the poor motivation of farmers of this commune to create a change to solve the problems of waste.

Environmental factors were not the driven of change but the production plan and the time consumption of waste treatment methods and the economic values

The correlation analysis pointed out that, in contrast to study's assumption, there was no evidences to confirm household intention has relationship with current farming scale and cow production experience. Especially household perceptions on the environmental and economic effectiveness of their current systems were not the predicted driven factors, except criteria related to the time. Even the case of no-treatment system household, we found no existed relationship according to the results of data analysis. In overall, the production plan had the highest correlation coefficients with household intention, especially when farmer plan to expand farming scale or cow barn. In addition, study also found the positive correlation between household intention and cultivation area and compost application cases which is possible has relationship with the time consumption criteria.

The findings of this study somewhat do not support the previous research of Nguyen Ngoc Son and his colleagues in 2010 [9]. In the paper he indicated that, environmental improvement was one component factors of farmers' decision to build biogas digester, besides economic values. Though in this study we used different approach which required farmer express their attitudes and intention, the results still present an unanticipated findings. According to a statement of Ajzen and his colleagues [11, 12], the intention will lead to the behavior in practice and the intention usually being driven by underpin factors. The exclusion of 
environmental factors in households' attitude draws out a serious scenario in Le Chi Commune in term of improving the current circumstance. If farmers remain the present farm size, they would possible pay little efforts on improving waste treatment system, which presently produce significant negative impacts on environment. These poor motivation states that, it needs to improve pro-environmental attitudes for farmers in order to target better waste management plan. In addition, many researchers stated that the supervise form experts and local staffs, the environmental communication campaigns to spread out skills and new technologies are not enough, it also needs strong enforcement of local government as well as other related institutions $[13,14]$.

\section{Conclusion}

In the near future, Vietnam could not deny the important role of household farming scale for economic growth and poverty reduction. However, the difficulties of waste management at household level are obviously visible. Understanding internal factors which affect behavior of the household is extremely important to obtain successful waste management campaign. The results of study pointed out that, some innovations in term of cow waste treatment were not been disseminated in this area, even this place locates in a peri-area of Ha Noi Capital. In addition, farmers tend to less motivate to change or improve the waste treatment situation, except when it connects to their interest (obtaining fertilizer for crops) or increase farming scale. Environmental aspects were not considered as the driven factors of change and that could result in few number of farmers intent to upgrade their current waste treatment system. The findings of this study suggest that, actually, the farmers do not process the ideas of environmental protection as researchers assumed they do. The linkage between the sustainability of the environment and their well-being probably has not been explored and being considered as driven factors of their own decision and attitude. The results indicate that it is extremely important to educate farmers to change their attitudes and behavior about environmental features and this factor should be taken into account in their actions or intention.

Although this study provides useful information about the factors which influence the intention of farmers who intend to upgrading their waste treatment system, there are limitations to the approach taken. Firstly, only internal factors of the household were considered in analysis computation, thus, some important factors might be missing. Secondly, the study was conducted in a small commune so it might be not present to significant common aspects of small scale cow waste management in Vietnam. These concerns could be resolved by other research in the future.

\section{Acknowledgement}

Author acknowledges the contribution of investigation team: Man Thi Huyen, Hoa Van Huynh, Vi Thi Luu, Nguyen Thi Quynh Mai, Thuong Thi Nga, Ha Thi Thu Phuong, Tran Anh Quan, Doan Thu Trang, Nguyen Thi Thu Trang.

\section{References}

[1] Bộ TN \& MT. Môi trường nông thôn - Báo cáo môi trường quốc gia 2014, Nhà xuất bản Tài nguyên - Môi trường và Bản đồ Việt Nam, Hà Nội. 2014.

(MONRE. Rural Environment - National Environmental Report, The Ministry of Natural Resource and Environment, Natural Resource and Environment Publisher, Ha Noi, 2014.).

[2] Vũ Thị Thanh Hương, Vũ Quốc Chính, Nguyễn Thị Hà Châu, Lê Văn Cư. Kết quả nghiên cứu thực trạng và các giải pháp quản lý môi trường trong chăn nuôi hộ gia đình và trang trại nhỏ ở một số tỉnh miền Bắc, Tạp chí Khoa học Công nghệ và Thủy lợi, No (18). 2013. 1 
(Vu Thi Thanh Huong, Vu Quoc Chinh, Nguyen Thi Ha Chau, Le Van Cu (2013). Studying situation and solution for managing environment in livestock farming at small-scale in some mountainous provinces in the Northern of Vietnam, Journal of Science Technology and Irrigation, No.18. 2013.1)

[3] Bộ TN \& MT. Báo cáo hiện trạng môi trường quốc gia giai đoạn 2011-2015, Nhà xuất bản Tài nguyên - Môi trường và Bản đồ Việt Nam, Hà Nội, 2015.

(MONRE. National Environmental Report for the period of 2011-2015, The Ministry of Natural Resource and Environment, Natural Resource and Environment Publisher, Ha Noi, 2015)

[4] Đinh Thị Hải Vân, Võ Hữu Công, Cao Trường Sơn, Nguyễn Thanh Lâm, Phạm Ngọc Bảo, Tetsuo Kuyama. 2017. Current Situation of Pig manure and Effluent Management in Viet Nam. Proceeding of The 12th International Symposium on Southeast Asian Water Environment

[5] Trần Thuý."Dân bức xúc với tình trạng ô nhiễm ở xã Lệ Chi, Gia Lâm”. 2016. Truy cập tại: http://cand.com.vn/dieu-tra-theo-don-bandoc/dan-buc-xuc-truoc-tinh-trang-o-nhiem-o-xaLe-Chi-Gia-Lam-391955/

(Tran Thuy. Public complains with environmental pollution in Le Chi Commune, Gia Lam. 2016. Achieved online at: http://cand.com.vn/dieu-tratheo-don-ban-doc/dan-buc-xuc-truoc-tinh-trang-onhiem-o-xa-Le-Chi-Gia-Lam-391955/)

[6] Trung tâm Quan trắc môi trường - Tổng cục Môi trường.. Báo cáo đánh giá hiệu quả của dự án quản lý chất thải vật nuôi ở Đông Nam Á. 2011. Hà Nội.

CEM. Assessment reports on livestock waste management in Southeast Asia project. Center of Environmental Monitoring. The General Department of Environment.2011. Ha Noi.

[7] Phùng Đức Tiến. Nguyễn Duy Điều. Hoàng Văn Lộc. Bạch Thị Thanh Dân. Đánh giá thực trạng ô nhiễm môi trường trong chăn nuôi. Tạp chí Chăn nuôi số 4/2009. Trang 10-
(Phung Duc Tien, Nguyen Duy Dieu, Hoang Van Loc \& Bach Thi Thanh Dan. Evaluating the status of environmental pollution in livestock farming. Journal of Livestock. 4/2009: 10)

[8] Đinh Văn Dũng, Lê Đình Phùng, Nguyễn Thị Tường Vy, Lê Đức Ngoan (2017). Hiện trạng và kịch bản giảm phát thải khí Metan từ hệ thống nuôi bò thịt thâm canh quy mô nông hộ ở Quảng Nam. Tạp chí Nông nghiệp và Phát triển Nông thôn số 1 .

(Dinh Van Dung, Le Dinh Phung, Nguyen Thi Tuong Vy \& Le Duc Ngoan (2017),Status of Methane gases emission form intensive beef cattle production at household scale in Quang Nam, The Journal of Agriculture and Rural Development, No.1)

[9] Rajendran, K., Aslanzadeh, S. \& Taherzaded,M. Household Biogas Digesters - A review. Energies. No. 5. 2012. 2911

[10] Nguyen Ngoc Son, Huynh Cam Linh and Dang Kieu Nhan. Assessment of main factors effecting adaption of biogas in integrated VAC-B farming system in freshwater area of the Mekong Delta Journal of Science.No15a. 2010. 64

[11] Ajzen, I . "The theory of planned behavior". Organizational Behavior and Human Decision Processes. 50 (2).1991. 179

[12] Ajzen, I. \& Fishbein, M. Understanding attitudes and predicting social behavior. Englewood Cliffs, NJ: Prentice Hall. 1980.

[13] Ali N.E. \& Siong H.C. Social Factors Influencing Household Solid Waste Minimisation. MATEC Web of Conference 66. 2016. Achieved online at: https://www.matecconferences.org/articles/matecconf/pdf/2016/29/m atecconf_ibcc2016_00048.pdf

[14] McAllister, J. (2015) Factors Influencing SolidWaste Management in the Developing World. Master Thesis, Utah State University. Achieved online

at: https://digitalcommons.usu.edu/cgi/viewcontent.c gi? article $=1537 \&$ context $=$ gradreports 


\title{
Phân tích các nhân tố bên trong ảnh hưởng tới ý định nâng cấp hệ thống xử lý chất thải của hộ gia đình: Nghiên cứu trường hợp hộ chăn nuôi bò quy mô nhỏ tại xã Lệ Chi, Gia Lâm, Hà Nội
}

\author{
Nguyễn Thị Hương Giang \\ Bộ môn Quản lý môi trường, Khoa Môi truờng, Học viện Nông nghiệp Việt Nam, \\ Trâu Quỳ, Gia Lâm, Hà Nội, Việt Nam
}

Tóm tắt: Quản lý chất thải chăn nuôi quy mô nông hộ là một trong những thách thức lớn ở Việt Nam trong nhiều năm nay. Hiểu được các nhân tố tác động bên trong ảnh hưởng tới hành vi của các hộ gia đình là một trong những yếu tố quan trọng để đạt được thành công trong các chương trình quản lý chất thải. Nghiên cứu được triển khai trên một xã thuộc ngoại thành Hà Nội, xã Lệ Chi nhằm cung cấp những thông tin hữu ích giúp hiểu rõ hơn những hoạt động liên quan đến xử lý chất thải của nông hộ. Trong cách tiếp cận nghiên cứu hành vi, nghiên cứu đã tiến hành phỏng vấn 85 hộ gia đình sản xuất bò thịt để thu thập các thông tin cần thiết cho mô hình phân tích tương quan và hồi quy. Kết quả nghiên cứu đã chỉ ra rằng, không có bằng chứng chứng minh mối liên quan giữa ý định nâng cấp hệ thống của nông hộ với quy mô sản xuất cũng như quan điểm liên quan đến tính hiệu quả về mặt môi trường của hệ thống xử lý hiện có. Mặc dù vậy, ý định này lại tương quan rõ rệt với các kế hoạch sản xuất trong tương lai nhất là việc mở rộng quy mô sản xuất, chuồng trại $(\mathrm{r}=.490, \mathrm{p}=.001, \mathrm{r}=.675, \mathrm{p}<.001)$ và cả sự hài lòng về tiêu chí tiết kiệm thời gian của phương pháp xử lý hiện tại $(\mathrm{r}=-.304, \mathrm{p}<0.001)$.. Kết quả từ nghiên cứu này đã cung cấp các thông tin cần phải cân nhắc cho các chiến lược quản lý chất thải chăn nuôi trong thời gian sắp tới của xã.

Tù khoá: Quản lý chất thải, ý định của nông hộ, hành vi bảo vệ môi trường, thái độ bảo vệ môi trường. 